\title{
Physicochemical Characterization of Heat-induced Soluble Aggregates of Bovine Globin
}

\author{
Shigeru Hayakawa, Yasuyo Suzuki, Ryo NaKamura \\ and Yasushi SATO* \\ Department of Food Science and Technology, Nagoya University, \\ Chikusa-ku, Nagoya 464, Japan \\ * Department of Agricultural Chemistry, Meijo University, \\ Tenpaku, Nagoya 468, Japan \\ Received September 6, 1982
}

\begin{abstract}
Physicochemical properties of heat-induced soluble aggregates of bovine globin were studied with several physicochemical measurements and electron microscopy.

A great change in ellipticity and formation of soluble aggregates of globin occurred between 45 and $50^{\circ} \mathrm{C}$.

Soluble aggregates of globin formed below $60^{\circ} \mathrm{C}$ were globular particles with a diameter of 15 to $20 \mathrm{~nm}$ and a sedimentation coefficient and molecular weight of approx. $20 \mathrm{~S}$ and $8 \times 10^{5}$, respectively. Their solutions were not so highly viscous. On the other hand, soluble aggregates of globin formed above $80^{\circ} \mathrm{C}$ were fibrous macro-aggregates with a thickness of 8 to $10 \mathrm{~nm}$ of which the sedimentation coefficient and molecular weight were above $50 \mathrm{~S}$ and $10^{6}$ to $10^{8}$, respectively. Their solutions were highly viscous.

It is suggested that a great increase in globin viscosity on heating takes place through the following process; globular aggregates are formed spontaneously with the unfolding of globin molecules, and subsequently fibrous macro-aggregates are formed via extension and association of globular aggregates. It is also considered that fibrous macro-aggregates might form a gel at a higher concentration.
\end{abstract}

The annual production of blood from slaughtered amounts to about 80 million kilograms in Japan. This blood contains about $18 \%$ protein and hemoglobin accounts for more than half of the blood protein. Most of the hemoglobin is not utilized for human consumption at present in Japan because of its disagreeable color and odor.

Bovine globin with a slightly yellow color was prepared from bovine hemoglobin by treatment with acidified acetone, ${ }^{1,2)}$ hydrogen peroxide $^{3)}$ or a proteolytic enzyme. ${ }^{4)}$ Recently, Sato et al., ${ }^{5)}$ prepared globin with an amino acid composition similar to the original hemoglobin from several kinds of animal blood by using a CM cellulose procedure.

From nutritional studies it is knwon that the chemical score of bovine globin is very low due to the lack of isoleucine and low methionine content. ${ }^{6 \sim 10)}$ However, this does not present any serious problem in the utilization of globin because its digestibility is extremely high, ${ }^{7)}$ and the biological value or protein efficiency ratio can be greatly improved by supplementation with isoleucine and methionine, or cereal protein isolates. ${ }^{7 \sim 9)}$

Successful supplementation to food, and the replacement or simulation of traditional proteinaceous foods will depend on the availability of new proteins having critical functional characteristics which enable them to be used and to be acceptable to people. ${ }^{11)}$ Some functional properties of globin such as solubility, ${ }^{1,2,10,12,13)}$ emulsifying properties ${ }^{1,2,10,12)}$ and foaming properties ${ }^{2,10)}$ have been characterized by several workers. Attempts have been made to incorporate globin into sausagemeat, ${ }^{14)}$ and a cheese-like emulsion was prepared using globin as an ingredient. ${ }^{15}$ ) In the previous work, ${ }^{13)}$ it was found that a globin 
solution heated above $80^{\circ} \mathrm{C}$ was highly viscous and formed a transparent gel at the concentration of above $3 \%$ under well controlled heat conditions, suggesting that globin forms soluble aggregates on heating. However, little is known as to the properties of soluble aggregates of globin and the process of thermal aggregation and formation of a transparent gel.

The purpose of the present study was to determine the physicochemical characteristics of soluble globin aggregates formed at various temperatures and to discuss the process of gel formation of globin.

\section{MATERIALS AND METHODS}

Preparation of bovine globin. Hemoglobin prepared from bovine blood by the method described in the previous study ${ }^{13)}$ was further purified by DEAE cellulose column chromatography. ${ }^{16)}$ Bovine globin was prepared from the purified hemoglobin using the CM cellulose procedure described in the previous article. ${ }^{13)}$

Heating conditions. Bovine globin was mainly heated at a concentration of $1 \%$ in $0.025 \mathrm{~m}$ sodium acetate buffer,

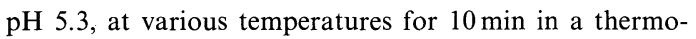
bath controlled within $\pm 1^{\circ} \mathrm{C}$.

Circular dichroism analysis. Circular dichroism experiments were carried out with a JASCO J-40A spectropolarimeter in a $1 \mathrm{~mm}$ cell at $25^{\circ} \mathrm{C}$, at a protein concentration of $0.2 \mathrm{mg} / \mathrm{ml}$. The data were expressed in terms of mean residue ellipticity, taking the mean residual weight of globin as 108. Temperature dependence of the circular dichroism spectrum of globin was measured at a constant wavelength of $222 \mathrm{~nm}$, raising the temperature from 25 to $55^{\circ} \mathrm{C}$ at a rate of $2^{\circ} \mathrm{C} / \mathrm{min}$. The concentration of the globin solution was $0.1 \mathrm{mg} / \mathrm{ml}$ in $0.025 \mathrm{M}$ sodium acetate buffer, $\mathrm{pH}$ 5.3.

Measurement of sedimentation coefficient. Sedimentation coefficients were measured with an ultracentrifuge (Hitachi UCA 1A) at $27,160,43,700$ or $60,000 \mathrm{rpm}$ and $25^{\circ} \mathrm{C}$ in $0.025 \mathrm{~m}$ sodium acetate buffer, $\mathrm{pH} 4$ to 5.8 , at a globin concentration of $0.5 \mathrm{~g} / 100 \mathrm{ml}$. All values were normalized to $20^{\circ} \mathrm{C}$ with pure water as the solvent. The relative ratio of aggregates was calculated from the peak area of the fast sediment component per total peak areas of fast and slow sediment components.

Gel filtration. Gel filtration was performed on a Sephacryl S 200 column $(1.6 \times 40 \mathrm{~cm})$ using $0.025 \mathrm{M}$ so- dium acetate buffer, $\mathrm{pH}$ 5.3, for elution buffer. Each eluated fraction $(3 \mathrm{ml})$ was monitored at $280 \mathrm{~nm}$. The relative ratio of aggregates was calculated from the peak area monitored at $280 \mathrm{~nm}$.

Electrophoresis. Electrophoresis was performed on $4.5 \%$ flat bed polyacrylamide gel ( $\mathrm{pH} 4.3$ ) containing $0.06 \mathrm{M}$ $\mathrm{KOH}$ and $0.378 \mathrm{M}$ acetic acid. The electrophoresis was conducted at $4 \mathrm{~mA} / \mathrm{cm}^{2}$ and for $6 \mathrm{hr}$ using a running buffer ( $\mathrm{pH} 4.5$ ) consisting of $0.35 \mathrm{~m} \beta$-alanine and $0.14 \mathrm{M}$ acetic acid. The gel was stained with $0.5 \%$. Coomassie brilliant blue R250 and destained with 7\% acetic acid containing $10 \%$ methanol. The gel was densitometrically monitored with a Shimadzu Dual Wavelength Scanner CS 910. The relative ratio of aggregates was calculated from the peak area of non-aggregated components for heated globin per that for unheated globin. The relative ratio of aggregates was averaged for 3 to 5 runs.

Viscosity measurement. Viscosities of heated globin solutions were measured with an Ostwald viscometer having a flow time of $114 \mathrm{sec}$ for water at $20^{\circ} \mathrm{C}$. Reduced viscosity was calculated from relative viscosity based on the concentration of heated globin determined by the method of Lowry et $a l .{ }^{17)}$ Intrinsic viscosity was determined by extrapolating reduced viscosity to a concentration of zero.

Density gradient ultracentrifugation. Heated globin $(5 \mathrm{mg})$ was centrifuged in $12 \mathrm{ml}$ of a 5 to $30 \%(\mathrm{w} / \mathrm{v})$ linear sucrose gradient containing $0.025 \mathrm{M}$ sodium acetate buffer, $\mathrm{pH} 5.3$, in a Hitachi RPS $40 \mathrm{~T}$ rotor at $25,000 \mathrm{rpm}$ for $15 \mathrm{hr}$ at $10^{\circ} \mathrm{C}$. The gradient was fractionated into $0.6 \mathrm{ml}$ portions with monitoring at $280 \mathrm{~nm}$ with an ISCO density gradient fractionator. The protein content of each fraction was determined by the Bio-Rad protein assay method.

Light scattering. Light scattering measurements were performed with a low angle laser light scattering photometer (Chromatix KMX-6, Sunnyvale, USA). The laser was a $2 \mathrm{~mW} \mathrm{He-Ne} \mathrm{unit} \mathrm{operating} \mathrm{at} \mathrm{the} \mathrm{red} \mathrm{wavelength} \mathrm{of}$ $632.8 \mathrm{~nm}$. The scattering angle was $4.5^{\circ}$. All measurements were performed at $20^{\circ} \mathrm{C}$. The protein concentration $(0.1 \sim 0.2 \mathrm{mg} / \mathrm{ml}$ for heated globin and $1 \sim 3 \mathrm{mg} / \mathrm{ml}$ for unheated globin) was determined by the method of Lowry et $a l .{ }^{17)}$ Refractive increments of unheated and heated globin at $60^{\circ} \mathrm{C}$ were measured with a laser differential refractometer (Chromatix KMX-16, Sunnyvale, USA) at a wavelength of $633 \mathrm{~nm}$. The molecular weight of heated globin was calculated from the Rayleigh factor and refractive increment of 0.1564 for unheated and heated globin.

Electron microscopy. A Hitachi electron microscope $\mathrm{HU}$ $12 \mathrm{~A}$ was used at an accelerating voltage of $75 \mathrm{kV}$. A globin solution was diluted 100 -fold after heat treatment. A small drop was applied to a carbon-coated copper grid, and $3 \%$ uranyl acetate was used for staining. 


\section{RESULTS}

Figure 1 shows circular dichroism spectra for globin heated at $\mathrm{pH} 5.3$ and various temperatures. Both unheated and heated globin showed minimum ellipticity at around $222 \mathrm{~nm}$ and $208 \mathrm{~nm}$. Negative ellipticity of globin at $222 \mathrm{~nm}$ greatly decreased on heating between 45 and $50^{\circ} \mathrm{C}$. The temperature dependence experiment also showed a great change of ellipticity at $222 \mathrm{~nm}$ between 45 and $50^{\circ} \mathrm{C}$. Therefore, it was considered that the globin molecules unfolded between 45 and $50^{\circ} \mathrm{C}$. Negative ellipticity showed a slight decrease between 60 and $80^{\circ} \mathrm{C}$. This decrease may be attributed to the contamination by a small amount of hemoglobin $(3 \sim 5 \%$ in globin preparation) with a melting point value of $67^{\circ} \mathrm{C}^{18,19)}$

Sedimentation coefficients of globin heated at various $\mathrm{pHs}$ and temperatures are shown in Table I. The globin solution heated at $\mathrm{pH} 5.8$ was turbid and coagulated above $60^{\circ} \mathrm{C}$, whereas that heated at $\mathrm{pH} 4.0$ formed no aggregate. The globin solution heated at $\mathrm{pH} 5.3$ was clear up to $90^{\circ} \mathrm{C}$ and that heated at $95^{\circ} \mathrm{C}$ was a gel-like coagulate. Two distinct peaks

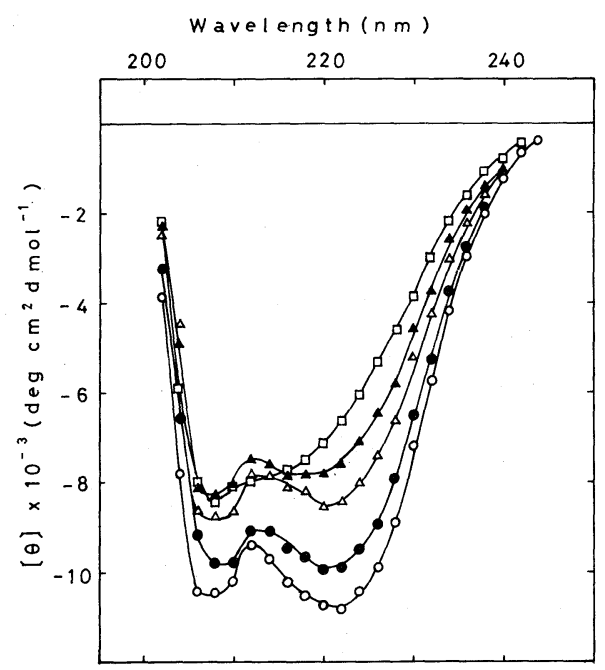

FIG. 1. Circular Dichroism Spectra of Globin Heated at Various Temperatures.

$\mathrm{O}$, unheated and heated at $40^{\circ} \mathrm{C}$; $55^{\circ} \mathrm{C}$ and $60^{\circ} \mathrm{C} ; \square, 80^{\circ} \mathrm{C}$. were observed when globin was heated at $\mathrm{pH}$ 5.3 and $50^{\circ} \mathrm{C}$. One was a non-aggregate which disappeared above $60^{\circ} \mathrm{C}$, and the other was a

\section{Table I. Sedimentation Coefficients of Globin Heated at Various pHs AND TEMPERATURES}

All values are shown as $S_{20, w}$ at a protein concentration of $5 \mathrm{mg} / \mathrm{ml}$. When heated globin showed two peaks, both sedimentation coefficients are shown in the table, that of the minor peak being in parentheses.

\begin{tabular}{|c|c|c|c|c|}
\hline \multirow{2}{*}{$\begin{array}{l}\text { Heating } \\
\text { temp. }\left({ }^{\circ} \mathrm{C}\right)\end{array}$} & \multicolumn{4}{|c|}{$\mathrm{pH}$} \\
\hline & 4.0 & 4.8 & 5.3 & 5.8 \\
\hline 30 & 1.9 & 2.9 & 3.7 & $\begin{array}{c}4.6 \\
(21.6)\end{array}$ \\
\hline 40 & nd & 3.2 & 4.6 & $\begin{array}{r}6.0 \\
24.4\end{array}$ \\
\hline 50 & nd & $\begin{array}{c}3.5 \\
(14.1)\end{array}$ & $\begin{array}{r}5.4 \\
22.2\end{array}$ & 31.6 \\
\hline 60 & nd & $\begin{array}{r}3.8 \\
18.2\end{array}$ & 23.1 & 70.3 \\
\hline 70 & nd & $\begin{array}{r}5.4 \\
21.7\end{array}$ & 29.8 & \\
\hline 80 & 1.7 & $\begin{array}{r}3.3 \\
33.1\end{array}$ & 52.7 & \\
\hline 90 & nd & $\begin{array}{r}9.7 \\
39.9\end{array}$ & 63.3 & \\
\hline 100 & 2.1 & $\begin{array}{r}2.6 \\
50.2\end{array}$ & & \\
\hline
\end{tabular}

nd, not determined.

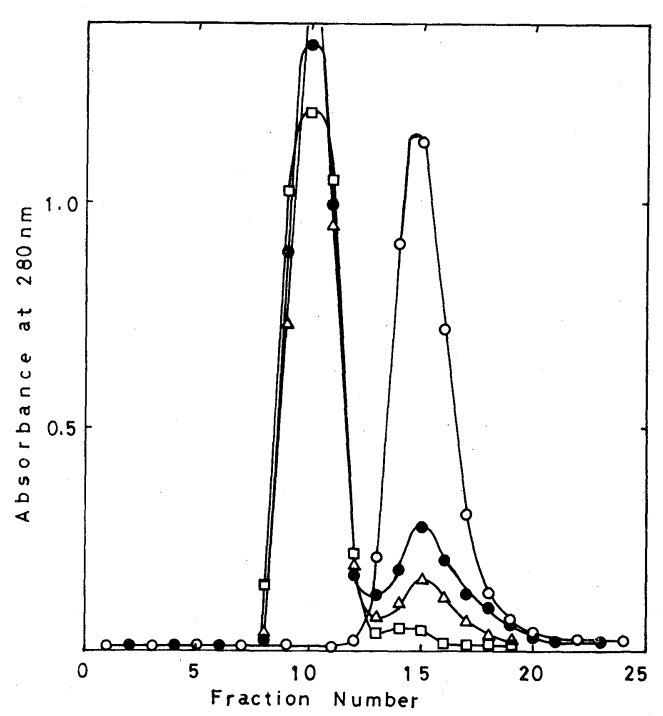

FIG. 2. Elution Patterns of Gel Filtration on a Sephacryl $S 200$ for Globin Heated at Various Temperatures.

○, unheated; $\bigcirc 50^{\circ} \mathrm{C} ; \triangle, 60^{\circ} \mathrm{C} ; \square, 80^{\circ} \mathrm{C}$. 
soluble aggregate having a sedimentation coefficient of approx. $20 \mathrm{~S}$. This soluble aggregate showed little increase in sedimentation coefficient but an increase in amount when heated at $60^{\circ} \mathrm{C}$. The sedimentation coefficient of heated globin greatly increased above $80^{\circ} \mathrm{C}$.

Figure 2 shows the elution pattern of gel filtration for heated globins. Unheated globin showed a single peak corresponding to the non-aggregate and globin heated above $50^{\circ} \mathrm{C}$ showed an additional peak at a void volume corresponding to the aggregate. The higher the temperature was, the smaller the peak of the non-aggregate.

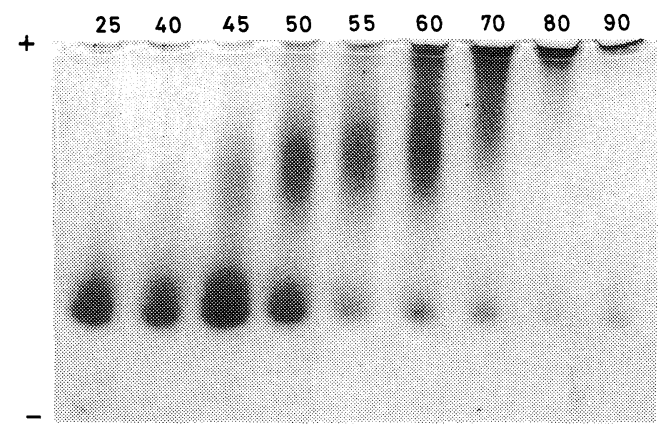

Fig. 3. Electrophoretic Patterns of Globulin Heated at Various Temperatures.

Heating temperatures are shown in the figure.

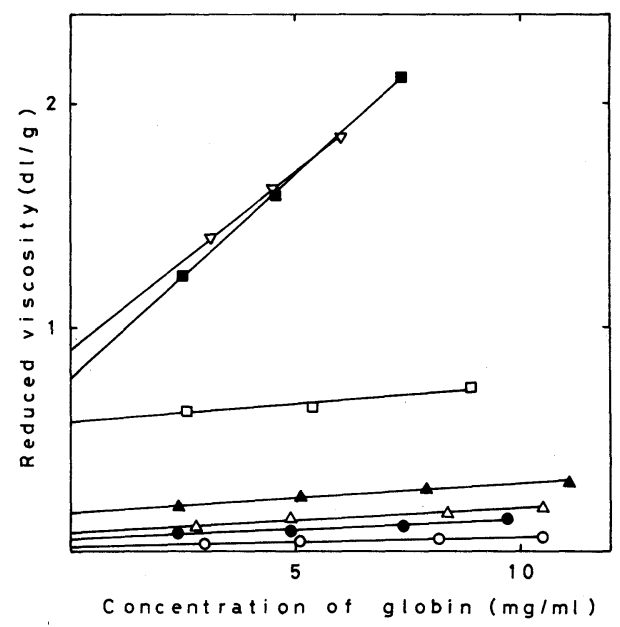

FIG. 4. Concentration Dependence of Reduced Viscosity of Globin Heated at Various Temperatures.

○, unheated;, $50^{\circ} \mathrm{C} ; \triangle, 60^{\circ} \mathrm{C} ; \Delta, 70^{\circ} \mathrm{C} ; \square, 80^{\circ} \mathrm{C}$; $90^{\circ} \mathrm{C} ; \nabla, 60^{\circ} \mathrm{C}$ and subsequently at $90^{\circ} \mathrm{C}$.
Figure 3 shows the electrophoretic patterns of the heated globins. The amount of the fast moving component considered to be a nonaggregate decreased on heating above $45^{\circ} \mathrm{C}$, and the amount of the slow moving com-

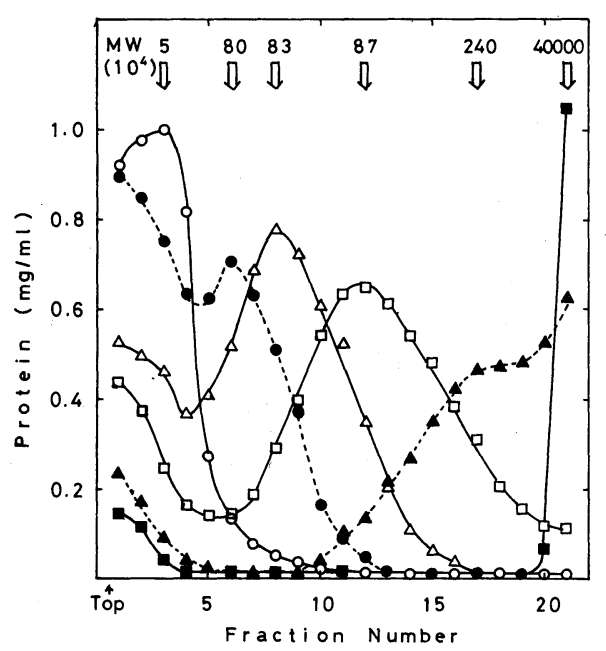

FIG. 5. Density Gradient Ultracentrifugal Patterns of Globin Heated at Various Temperatures and Molecular Weights of Their Peak Fractions Estimated by Light Scattering.

○, unheated;, $50^{\circ} \mathrm{C} ; \triangle, 60^{\circ} \mathrm{C} ; \square, 70^{\circ} \mathrm{C} ; \Delta, 80^{\circ} \mathrm{C} ; \boldsymbol{\square}$, $90^{\circ} \mathrm{C}$.

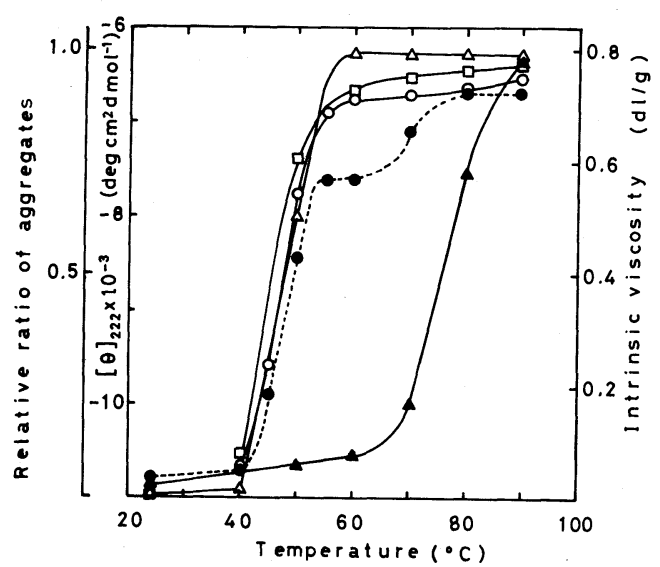

FIG. 6. Mean Residual Ellipticity at $222 \mathrm{~nm}$, Relative Ratio of Aggregates and Intrinsic Viscosity of Globin Heated at Various Temperatures.

-, ellipticity; $\bigcirc$, relative ratio of aggregates by electrophoresis; $\square$, relative ratio of aggregates by ultracentrifugation; $\triangle$, relative ratio of aggregates by gel filtration; $\boldsymbol{\Delta}$, intrinsic viscosity. 
ponent considered to be a soluble aggregate increased with raising of the temperature to $60^{\circ} \mathrm{C}$. Little globin heated above $80^{\circ} \mathrm{C}$ migrated into the gel.

Figure 4 shows the concentration dependence of reduced viscosities of heated globins. Reduced viscosities of globin heated above $80^{\circ} \mathrm{C}$ were extremely high, whereas only a slight increase in reduced viscosity was observed on heating below $70^{\circ} \mathrm{C}$. Reduced viscosity of globin heated at $90^{\circ} \mathrm{C}$ showed a high concentration dependence as well as that of that heated at $60^{\circ} \mathrm{C}$ and then $90^{\circ} \mathrm{C}$.

Figure 5 shows the patterns of density gradient ultracentrifugation of heated globins and the molecular weights (MW) of their peak fractions determined by light scattering. The peak tended to move to a higher density, the higher the temperature was. The MWs of peak fractions of globin heated at 50 to $70^{\circ} \mathrm{C}$ were around $8 \times 10^{5}$. The average $\mathrm{MW}$ of the whole fraction of globin heated at $80^{\circ} \mathrm{C}$ was $2.3 \times 10^{7}$ and that of the peak fractions was $2.4 \times 10^{6}$. The MW of globin heated at $90^{\circ} \mathrm{C}$ was extremely high $\left(4 \times 10^{8}\right)$.

Figure 6 shows the ellipticity at $222 \mathrm{~nm}$, the relative ratio of aggregates measured by three different methods and the intrinsic viscosity of globin heated at various temperatures. All the relative ratios of aggregates rapidly increased around $50^{\circ} \mathrm{C}$, and the tendency to increase coincided with the decrease of the negative
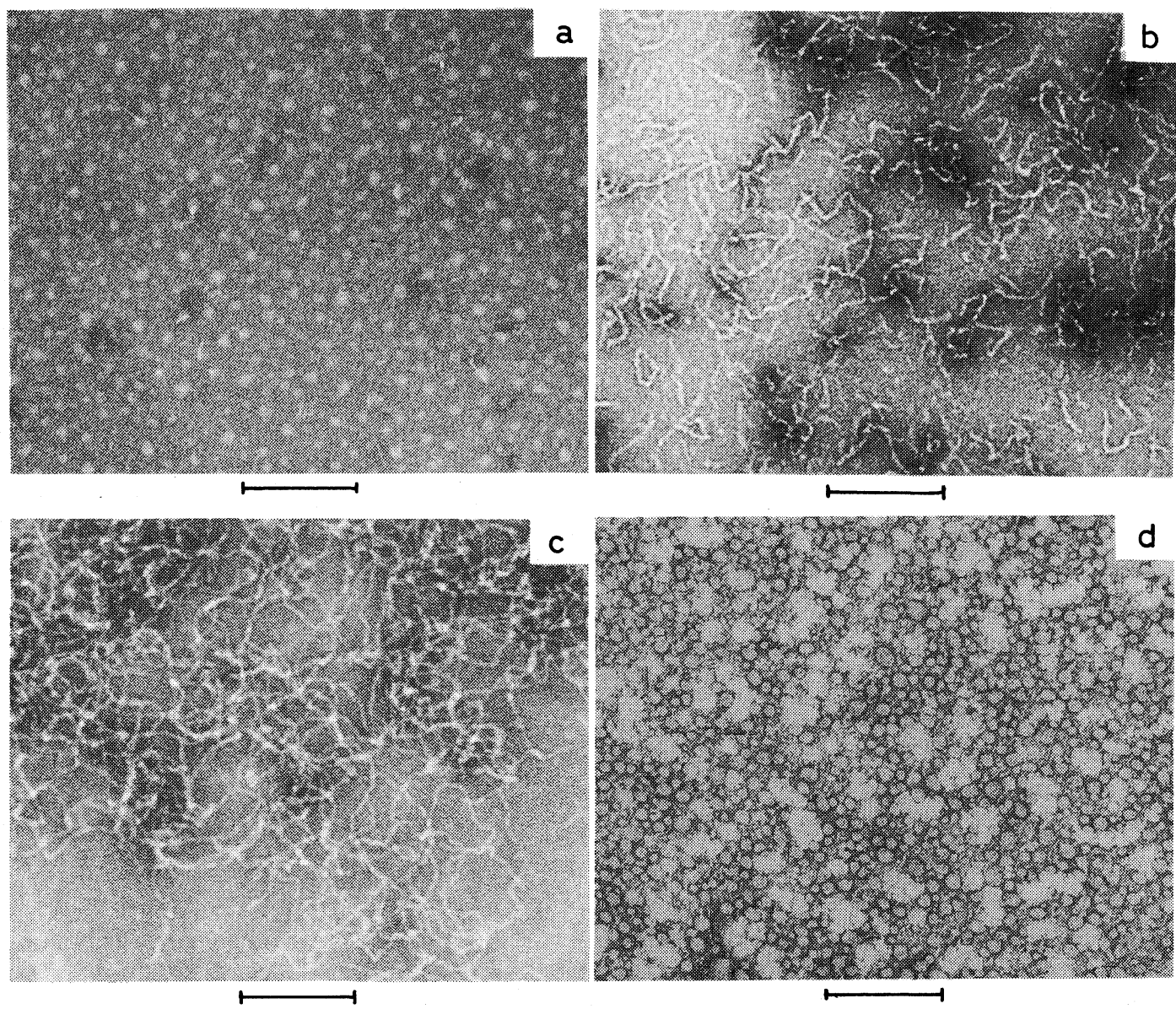

FIG. 7. Electron Micrographs of Hemoglobin and Globin Heated at Various Temperatures.

a) globin heated at $60^{\circ} \mathrm{C}$, b) globin heated at $80^{\circ} \mathrm{C}$, c) globin heated at $90^{\circ} \mathrm{C}$, d) hemoglobin heated at $80^{\circ} \mathrm{C}$. All bars indicate $200 \mathrm{~nm}$. 
ellipticity. However, the rapid increase in the intrinsic viscosity which occurred above $80^{\circ} \mathrm{C}$ was not coincident with an increase in the relative ratio of aggregates.

The physicochemical results for heated globin were supplemented by electron microscopic observation. Figure 7 shows electron micrographs of heated globin and hemoglobin. Soluble aggregates of globin formed by heating at $60^{\circ} \mathrm{C}$ were nearly globular particles with a diameter of 15 to $20 \mathrm{~nm}$ (Fig. 7a). On the other hand, those formed by heating at $80^{\circ} \mathrm{C}$ were like strands with a thickness of 8 to $10 \mathrm{~nm}$ (Fig. 7b). The globin heated at $90^{\circ} \mathrm{C}$ formed highly entangled fibrous aggregates with a thickness of 8 to $10 \mathrm{~nm}$ (Fig. 7c). The high concentration dependence of reduced viscosity in Fig. 4 was considered to be attributable to the entanglement of the fibrous globin aggregates. The latter were also observed when the globular particles formed by heating at $60^{\circ} \mathrm{C}$ were further heated at $90^{\circ} \mathrm{C}$ (not shown but almost the same as in Fig. 7c). Electron micrographs indicated that the linear aggregation predominantly occurred at the higher heating temperature (above $80^{\circ} \mathrm{C}$ ). Hemoglobin heated at $80^{\circ} \mathrm{C}$ formed aggregates consisting of globular aggregates with a diameter of 15 to $25 \mathrm{~nm}$, and larger aggregates composed of a number of globules (Fig. 7d).

\section{DISCUSSION}

The mean residue ellipticity of bovine globin prepared by the $\mathrm{CMC}$ procedure [globin (CMC)] was $-10,840$ at $222 \mathrm{~nm}$ (Fig. 1). Vodrazka et $a .^{20)}$ showed that the ellipticity of bovine hemoglobin and native globin prepared by an acidified acetone procedure [globin (acetone)] at $222 \mathrm{~nm}$ was $-24,500$ and $-17,500$, respectively, which corresponded to $73 \%$ and $49 \% \alpha$-helix contents calculated with the formulas of Chen and Yang. ${ }^{21)}$ They speculated that the lower helix content of globin compared to hemoglobin is due to the unfolding of regions that in hemoglobin are stabilized by interaction with the heme group. The $\alpha$-helix content of globin (CMC) was $28 \%$ when calcu- lated with the formulas of Chen and Yang. ${ }^{21)}$ This helix content was considerably lower than that of native bovine globin (acetone). It was shown that the native bovine globin obtained from the acidified acetone globin fraction by removal of the denatured molecules which were insoluble in a neutral medium represented approx. $10 \%$ of the globin fraction. ${ }^{20)}$ It was shown that a decrease in $\mathrm{pH}$ resulted in the unfolding of the human globin molecules, ${ }^{22)}$ and a major loss of about $35 \%$ helicity of water buffalo apomyoglobin occurred between $\mathrm{pH} 5.6$ and $4.3 .^{23)}$ Therefore, the lower helicity of globin (CMC) was due to the presence of denatured molecules and to the ellipticity at the slightly acid $\mathrm{pH}$. Although sedimentation coefficients of globin (CMC) were somewhat large $(3.7 \mathrm{~S}$ at $\mathrm{pH} 5.3,2.7 \mathrm{~S}$ at $\mathrm{pH} 4.8$ ) (Table I) compared to globin (acetone) (3.1 $S$ at $\mathrm{pH} 6.2,2.7 \mathrm{~S}$ at $\mathrm{pH} 4.8),{ }^{20)}$ globin (CMC) contained no aggregates (Figs. 2, 3). It has been considered that the acidified acetone procedure is a mild method for preparing globin, and hemoglobin with properties quite similar to those of the original hemoglobin can be reconstituted from globin (acetone) and heme. ${ }^{24)}$ Therefore, the CMC procudure was also considered to be a mild method to prepare globin.

A great decrease in negative ellipticity of heated globin was observed between 45 and $50^{\circ} \mathrm{C}$ (Fig. 1). It was suggested that unfolding of globin molecules may occur at this temperature. The temperature of half-precipitation caused by thermal denaturation of native human globin was reported to be around $40^{\circ} \mathrm{C}^{25,26)}$ The high denaturation temperature of globin in the present study may be attributable to the short heating time $(10 \mathrm{~min})$ and low $\mathrm{pH}$ (5.3), since the heating conditions for native human globin were $60 \mathrm{~min}$ at $\mathrm{pH} 7$. Soluble aggregates were also formed between 45 and $50^{\circ} \mathrm{C}$ (Fig. 6). Therefore, it is considered that the formation of soluble aggregates may occur spontaneously with the unfolding of globin molecules.

The soluble aggregates were globular particles with diameters ranging from 15 to $20 \mathrm{~nm}$ 
(Fig. 7a) and their sedimentation coefficient and molecular weight were approx. $20 S$ and $8 \times 10^{5}$, respectively (Table I, Fig. 5). It was estimated that a globular aggregate consisted of about fifty globin molecules with a molecular weight of about $16,000 .{ }^{27)}$ It was found that the globin was less stable than the hemoglobin, and the presence of aromatic and alicyclic hydrocarbons increased the resistance of the globin to heat denaturation. ${ }^{23)}$ The role of the hydrophobic bond in the slow and progressive aggregation of globin molecules at pHs above 3 has also been considered by Rossi-Franelli et al. ${ }^{24)}$ Therefore, it is considered that aggregation of globin molecules is due to their interaction with the hydrophobic regions exposed by the separation of the heme. It is also suggested that the interchain disulfide bond plays a minor role in forming an aggregate because bovine globin possesses no intramolecular disulfide bond and only $\beta$-globin has one sulfhydryl group ${ }^{27)}$ resulting in formation of dimeric $\beta$-globin. About two thirds of the globin molecules formed soluble aggregates within $30 \mathrm{sec}$ on heating at 60 or $70^{\circ} \mathrm{C}$ and their sedimentation coefficient showed only a slight increase after prolonged heating up to $30 \mathrm{~min}$ (data not shown). It may be considered that the definite size of the globular aggregates is due to their definite interactive surface area such as the hydrophobic regions of unfolded molecules and to little interaction between aggregates, because the hydrophobic regions on the surface of unfolded molecules are buried inside during the formation of aggregates.

The globin heated at $90^{\circ} \mathrm{C}$ formed fibrous macro-aggregates with a thickness of 8 to $10 \mathrm{~nm}$ (Fig. 7c), and with an extremely high molecular weight (Fig. 5) and a large sedimentation coefficient (Table I). Their solution was also extremely viscous. These huge aggregates in solution seem to be held by the critical balance between attractive and repulsive forces. Clark et al. ${ }^{28)}$ showed that linear aggregates were predominantly observed on electron microscopy in the aggregates of bovine serum albumin formed at sub-gelling con- centrations of protein and under the same conditions as produced the homogeneous gel networks. Tombs ${ }^{29)}$ suggested that strands must be formed by the aggregates to form a gel, and random aggregation would presumably lead to more or less spherical particles. It appears likely that hemoglobin aggregates randomly and globin forms strands (Fig. 7c, d). Thoms ${ }^{30)}$ also suggested that globular proteins form gels as a result of aggregation to form strands followed by interaction of the strands to form the gel mesh. Hermansson and Buchheim ${ }^{31)}$ found that the network structure of soy protein gel was formed at two levels, one of them being orientation on the molecular level in the form of strands. The globin can form a transparent gel at a higher concentration under the same heat conditions as in the present study, ${ }^{13)}$ so it is assumed that the three dimensional network formation of globin gel is formed from highly entangled fibrous macro-aggregates.

The thermal induced gelation of globin speculated from the present results is as follows. At first, globular aggregates with a molecular weight of approx. $8 \times 10^{5}$ are formed spontaneously with the unfolding of globin molecules. Secondly, the globular aggregates extend and associate to form fibrous macroaggregates with a high molecular weight of about $10^{8}$. Finally, the fibrous macroaggregates form a three dimensional network leading to formation of a gel. Mori et al. ${ }^{32)}$ also found that heat produced soluble aggregates as transient intermediates with a molecular weight $8 \times 10^{6}$ for soy protein. Therefore, it appears likely that globular protein tends to form heat-induced soluble aggregates as an intermediate form under appropriate conditions.

However, it is not clear that the formation of intermediates like globular aggregates is indispensable for formation of fibrous macroaggregates. It is not clear that globular and fibrous aggregates of the same size as formed at a sub-gelling concentration can be formed at the higher concentrations that produced the gel network. Therefore, further studies must be 
carried out on a very early stage of aggregation under the conditions of a higher protein concentration and high temperature.

Acknowledgments. The support of this project by the Ryoshoku Kenkyukai, Japan, is gratefully acknowledged. We also thank the Center for Chemical and Physical Analysis of the National Institute for Basic Biology for the use of the light scattering photometer.

\section{REFERENCES}

1) P. T. Tybor, C. W. Dill and W. A. Landman, J. Food Sci., 38, 4 (1973).

2) P. T. Tybor, C. W. Dill and W. A. Landman, J. Food Sci., 40, 155 (1975).

3) J. Wismer-Pedersen, Fleischwirtsch, 60, 987 (1980).

4) G. Drepper and K. Drepper, Fleischwirtsch, 59, 252 (1979).

5) Y. Sato, S. Hayakawa and M. Hayakawa, J. Food Technol., 16, 81 (1981).

6) M. D. Ranken, "Applied Protein Chemistry," ed. by R. A. Grant, Applied Science Publ., Ltd., 1980, p. 169.

7) A. V. Kuppevelt, G. Levin and P. Reizenstein, Nutri. Rep. Int., 13, 429 (1976).

8) W. A. Landman, C. W. Dill and C. R. Young, J. Nutr., 110, 2254 (1980).

9) E. L. Parmer, J. G. Surak and F. W. Knapp, J. Food Sci., 43, 499 (1978).

10) C. Devuono, M. Penteado, F. M. Lajolo and N. Pereira dos Santos, J. Sci. Food Agric., 30, 809 (1979).

11) J. E. Kinsella, CRC Crit. Rev. Food Sci. Nutr., 4, 219 (1976).

12) D. D. Crenwelge, C. W. Dill, P. T. Tybor and W. A. Landman, J. Food Sci., 39, 175 (1974).

13) S. Hayakawa, T. Ogawa and Y. Sato, J. Food Sci., 47, 1415 (1982).
14) H. A. Caldironi and H. W. Ockerman, J. Food Sci., 47, 405 (1982).

15) F. W. Knapp, R. H. Schmidt, W. J. Mauldin and E. M. Ahmed, J. Food Protection, 41, 257 (1978).

16) T. H. J. Huisman and A. M. Dozy, J. Chromatogr., 7, 180 (1962).

17) O. H. Lowry, N. J. Rosebrough, A. L. Farr and R. J. Randall, J. Biol. Chem., 193, 265 (1951).

18) B. Bull and K. Breese, Arch. Biochem. Biophys., 158, 681 (1973).

19) E. Stellwagen and H. Wilgus, Nature, 275, 342 (1978).

20) Z. Vodrazka, Z. Hrkal, M. B. Kodicek and D. Jandora, Eur. J. Biochem., 31, 296 (1972).

21) Y. H. Chen and J. T. Yang, Biochem. Biophys. Res. Commun., 44, 1285 (1971).

22) Z. Hrkal and Z. Vodrazka, Biochim. Biophys. Acta, 133, 527 (1967).

23) G. Colonna, G. Irace, G. Parlato, S. M. Aloj and C. Calesterieri, Biochim. Biophys. Acta, 532, 354 (1978).

24) A. Rossi-Fanelli, E. Antonini and A. Caputo, Advance in Protein Chemistry, 19, 73 (1964).

25) J. Sojika, H. Hrkal and Z. Vodrazka, Collect. Czech. Chem. Commun., 39, 509 (1974).

26) M. Kodicek and Z. Vodrazka, Collect. Czech. Chem. Commun., 41, 1811 (1976).

27) M. O. Dayhoff, "Atlas of Protein Sequence and Structure," Vol. 5, National Biomedical Foundation, Washington D. C., 1972.

28) A. H. Clark, F. J. Judge, J. B. Richards, J. M. Stubbs and A. Suggett, Int. J. Peptide Protein Res., 17, 380 (1981).

29) M. P. Tombs, "Protein as Human Food," ed. by R. A. Lawrie, Butterworth Publ., 1970, p. 126.

30) M. P. Tombs, Faraday Discuss. Chem. Soc., 57, 158 (1974).

31) A. M. Hermansson and W. Buchheim, J. Colloid Int. Sci., 81, 519 (1981).

32) T. Mori, T. Nakamura and S. Utsumi, J. Food Sci., 47, 26 (1981). 